
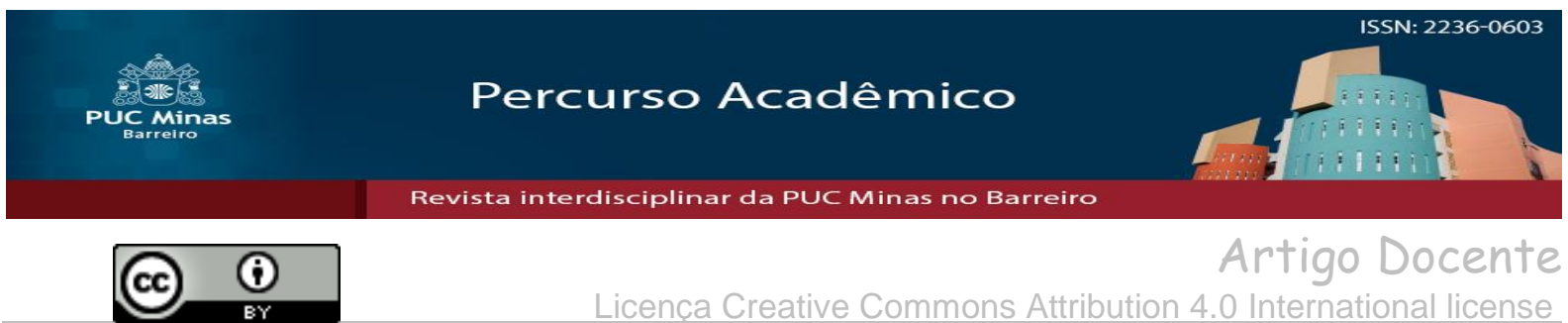

\title{
O cônjuge que comete homicídio doloso e a possibilidade de afastamento da meação por meio da declaração de indignidade
}

\section{Spouse that commit intentional homicide and removal of the possibility of sharecropping through the declaration of unworthiness}

\author{
Cláudia Mara de Almeida Rabelo Viegas ${ }^{1}$ \\ Natália de Souza Paula ${ }^{2}$
}

\begin{abstract}
Resumo
O presente estudo objetiva discutir a possibilidade de afastamento da meação do cônjuge considerado indigno, em face de cometimento de homicídio doloso, conduta prevista no Direito Sucessório Brasileiro como causa de afastamento do direito à herança, por indignidade. Pretende-se, pelo método indutivo e por meio de pesquisa bibliográfica e jurisprudencial, analisar a previsão legal, que conduz à interpretação de que o cônjuge indigno deixa de herdar, no entanto, erroneamente, recebe a sua meação, pela simples observância do Regime de Bens adotado pelo casal. A intenção central do artigo é demonstrar que a aplicação do princípio da justiça se mostra suficiente para afastar a interpretação literal do Código Civil, impondo novos efeitos à atitude indigna, de modo a alcançar a meação do cônjuge que cometeu homicídio doloso contra o seu parceiro. Seguindo essa linha, a fim de evitar injustiças e até mesmo a motivação para condutas atentatórias contra os autores da herança e seus herdeiros, defende-se uma interpretação legal teleológica, à luz do princípio da justiça, o qual justificará o afastamento do cônjuge da meação, quando este der causa a morte do autor da herança. $A$ justiça deve ser a principal virtude das instituições sociais, sendo, inclusive, inspiradora para pensar nova interpretação ao direito à meação, em caso de homicídio contra o consorte.
\end{abstract}

Palavras-chave: Indignidade. Herança. Meação. Cônjuge. Princípio da Justiça.

\begin{abstract}
The present study aims at discussing the possibility of removal of the spouse considered unworthy, due to the commission of willful homicide, conduct foreseen in the Brazilian Succession Law as a cause of removal of the right to inheritance, due to indignity. It is intended, through the inductive method and through bibliographical and jurisprudential research, to analyze the legal prediction, which leads to the interpretation of which the unworthy spouse ceases to inherit, however, erroneously, receives its mediation, for the simple observance of the Regime of Goods adopted by the couple. The central intention of the article is to demonstrate that the application of the principle of justice is sufficient to remove the literal interpretation of the Civil Code, imposing new effects on the unworthy attitude, in order to reach the position of the spouse who committed intentional homicide against his partner. Following this line, in order to avoid injustices and even the motivation for conduct that infringes upon the authors of the inheritance and their heirs, a teleological legal interpretation is defended in the light of the principle of justice, which will justify the separation of the spouse from the estate, when it causes the death of the author of the inheritance. Justice must be the main virtue of social institutions, and it is also inspiring to think a new interpretation of the right to mediation in the case of homicide against the consort.
\end{abstract}

Keywords: Unworthiness. Heritage. Sharecropping. Spouse. Principle of Justice.

Artigo recebido em 01 de maio de 2016 e aprovado em 07 de Agosto de 2017.

${ }^{1}$ Coordenadora do Curso de Direito da UNIESP - Faculdade de Belo Horizonte. Professora de Direito da PUC Minas, UNIESP, Conselho Nacional de Justiça e Polícia Militar de Minas Gerais. Doutora e Mestre em Direito Privado pela Pontifícia Universidade Católica de Minas Gerais. Servidora Pública Federal do TRT MG - Assistente do Desembargador Corregedor Dr. Fernando Antônio Viégas Peixoto. Especialista em Direito Processual Civil pela Universidade Gama Filho. Especialista em Educação à distância pela PUC Minas. Especialista em Direito Público - Ciências Criminais pelo Complexo Educacional Damásio de Jesus. Bacharel em Administração de Empresas e Direito pela Universidade FUMEC. Site: www.claudiamara.com.br. E-mail: claudiamaraviegas@yahoo.com.br.

Bacharel em Direito pela Pontifícia Universidade Católica de Minas Gerais. Advogada E-mail: natysouza.paula@hotmail.com. 


\section{Introdução}

O tema da indignidade certamente causa um sentimento de repulsa a qualquer um que dele toma conhecimento. No ordenamento jurídico pátrio, o assunto está inserido no Direito Sucessório e sua caracterização exige a observância de condutas específicas, que se comprovadas acarreta como principal efeito o afastamento do direito do herdeiro de receber seu quinhão hereditário.

Seguindo a interpretação literal do Direito Sucessório Brasileiro, o cônjuge que cometeu homicídio contra seu consorte, poderá ser considerado indigno de receber a herança, sendo-lhe garantido, no entanto, o recebimento da meação, nos regimes de casamento a ela inerente, posicionamento que se pretende afastar neste estudo.

O presente trabalho, portanto, propõe-se a demonstrar a possibilidade de aplicação analógica das consequências da decretação da indignidade, como fundamento suficiente a afastar o cônjuge indigno do seu direito à meação, pela simples observância do princípio da Justiça. Defende-se que não é legítimo o recebimento da meação, sobretudo, quando restar evidenciado o meio ilícito - homicídio - para obtenção deste direito.

Para tanto, utiliza-se, como metodologia, a revisão bibliográfica, apresentando o entendimento doutrinário, as leis e jurisprudências que tratam do tema, a fim de proporcionar um novo olhar sobre a indignidade do cônjuge.

O tema mostra-se de grande relevância, haja vista a possibilidade, diante da aplicação da letra fria da lei, da concretização de verdadeiras injustiças, "premiando" aquele que se casa e atenta contra a vida de outrem, com o único objetivo de acrescer a meação ao seu patrimônio.

Antes de adentrar no tema central, cumpre abordar, brevemente, os institutos da sucessão, herança, meação e indignidade, para, em seguida, perquirir a possibilidade de afastamento da meação, em caso de ato ilícito praticado contra o titular da herança.

Mostra-se de grande valor o estudo, pois o propósito é de propor o caminho para a concretização da verdadeira justiça. Em Estado Democrático, destinado a assegurar o exercício dos direitos sociais e individuais, a segurança, o bem-estar, o desenvolvimento, a igualdade, e, sobretudo, a justiça como valores supremos de uma sociedade fraterna, pluralista e sem preconceitos, não pode coadunar com a premiação do cônjuge indigno, que atenta contra a vida do parceiro, objetivando o recebimento da meação. 


\section{A sucessão}

Suceder é substituir, transmitir direitos e obrigações. A sucessão pode ser inter vivos, como exemplo a compra e venda de um imóvel; ou causa mortis, quando alguém titular de um patrimônio falece, transmitindo desde logo a herança aos seus herdeiros ou legatários os bens, incluindo direitos e deveres. (VENOSA, 2010).

A fundamentação da sucessão se deu originalmente por ordem religiosa. A família era governada pelo varão mais velho, descendente direto dos deuses domésticos, incumbindo-lhe administrar o patrimônio familiar e dirigir a vida religiosa e doméstica. A sucessão era transmitida ao homem, por ser ele o sacerdote da religião doméstica, circunstância que explicava a transmissão da herança ao primogênito varão.

Consoante Pereira (2015), a sucessão causa mortis, nessa época, se relacionava ao culto dos antepassados, inclusive, para os romanos, era obrigatório ter filhos para se perpetuar os cultos religiosos, contudo, não bastava apenas tê-los, sendo necessário que estes fossem frutos do casamento. À mulher não era permitido o comando ao culto dos antepassados. Ao se casar, esta saía do poder familiar do pai para ingressar no do cônjuge e, com o casamento a filha renunciaria à religião de sua família para integrar a do marido. A prevalência do homem na chefia do culto era tão relevante, que, se na linha da sucessão só tivesse mulheres, uma das filhas tinha que dar um neto para a continuação dos cultos. A intenção era de manter poderosa a família, coibindo a divisão patrimonial.

Concentrava-se a herança nas mãos de um único herdeiro do sexo masculino e a fundamentação da sucessão era pautada na religiosidade ou na família, ou seja, a partilha não era de forma igualitária, mas sim de forma desigual.

Com o decorrer do tempo, inovou-se a noção de que riqueza social é uma consequência da riqueza individual, tanto mais abastado e poderoso um agrupamento, mais ricos os indivíduos componentes. (HIRONAKA, 2007). Assim, a manutenção e a transmissão hereditária interessavam tanto ao ser quanto à sociedade.

No ordenamento jurídico brasileiro, o direito à herança é assegurado constitucionalmente, como direito fundamental, no artigo $5^{\circ}$, inciso XXX: "É garantido o direito à herança”. (BRASIL, 1988). 


\subsection{Espécies de sucessão e de sucessores}

A sucessão a ser abordada no presente artigo é a sucessão em sentido estrito, ou seja, decorrente da morte de alguém, sucessão causa mortis, na qual ocorre a transferência, total ou parcial, de herança, a um ou mais herdeiros, devido à morte de alguém.

As espécies de sucessão classificam-se em face dos efeitos que produz e da fonte da qual se origina. Esta pode ser legítima (ab intestato) ou testamentária, na forma do art. 1786, CC/02: “A sucessão dá-se por lei ou por disposição de última vontade”. (BRASIL, 2002).

Dessa forma, a sucessão por lei é a sucessão legítima, ao passo que a sucessão por disposição de última vontade se relaciona com a sucessão testamentária. Por outro lado, a classificação da sucessão, em face dos efeitos que produz, pode ser a título singular ou universal, circunstâncias que serão abordadas, de modo detalhado, a seguir.

\subsubsection{Sucessão a título universal}

A sucessão a título universal, assim como preconiza Diniz (2002, p.20) dá-se "quando houver transferência da totalidade ou de parte indeterminada da herança, tanto no seu ativo como no seu passivo, para o herdeiro do de cujus".

\footnotetext{
Haverá instituição de herdeiro, se o testador deixar ao beneficiário a totalidade de seu patrimônio ou uma porção abstrata de seus bens: meação, porção disponível, $1 / 3,1 / 4,1 / 5$ etc., todos os móveis ou imóveis existentes em certo município etc. O herdeiro é, portanto, chamado a suceder no todo ou numa quota-parte do patrimônio do de cujus, sub-rogando-se, abstratamente, na posição do falecido, como titular da totalidade ou de parte ideal daquele patrimônio no que concerne ao ativo, e assumindo a responsabilidade relativamente ao passivo. (DINIZ, 2002, p. 20).
}

A sucessão a título universal somente é admitida causa mortis, ou seja, o sucessor avoca a posição jurídico-econômica do autor da herança, ingressando-se na totalidade dos direitos que lhe pertenciam e que foram transmitidos em face do falecimento do titular.

Transmite-se como um todo ao seu sucessor o patrimônio do morto, compreendendo o ativo e o passivo; sendo débitos, créditos, obrigações, deveres e direitos, na proporção da herança herdada, salvo os direitos personalíssimos que não se transferem. É denominado herdeiro o sucessor a título universal, sucedendo na totalidade ou em parte da herança. 


\title{
1.1.2 Sucessão a título singular
}

$\mathrm{Na}$ sucessão a título singular, o autor da herança pode escolher seus herdeiros, destinando-lhes os bens na integralidade ou parcialmente, sendo os bens certos e determinados. Ao bem certo e determinado, ou individualizado, denomina-se legado. Diniz (2002, p. 20) corrobora com este entendimento:

\begin{abstract}
A título singular, quando o testador transfere ao beneficiário apenas objetos certos e determinados, p.ex.: uma joia, um cavalo, uma determinada casa na Rua " $\mathrm{X}$ " etc. Nessa espécie de sucessão é o legatário que sucede ao de cujus em bens ou direitos determinados ou individuados, ou em fração do patrimônio devidamente individuada, sub-rogando-se, de modo concreto, na titularidade jurídica de determinada relação de direito, sem representar o falecido, pois não responde pelas dívidas e encargos daherança, já que sucede apenas in rem aliquamsingularem. Portanto, seo testador contemplar alguém com uma coisa concreta, definida, singular, ter-se-á a nomeação do legatário.
\end{abstract}

No vigente Código Civil Brasileiro, em seus artigos 1.857, 2.014 e 2.018, pode-se verificar a sucessão a título singular. Cabe ressaltar que, em se tratando do artigo 2.018, do Código Civil, o testador pode fazer a partilha em vida, ainda que esta seja levada a efeito por testamento.

Na sucessão a título universal, o sucessor é o herdeiro, ao passo que, na sucessão a título singular, o sucessor é o legatário. Somente existe a figura do legatário, no testamento, em que os bens são caracterizados como legado. Não tendo o falecido deixado um testamento válido e eficaz, não haverá legado. Nesse sentido, destacam-se as diferenças entre herdeiro e legatário nas palavras de Venosa (2010, p. 8):

[...] Basta dizer, a princípio, que o legatário não tem a posse que detém o herdeiro com a abertura da sucessão. Como regra geral, o legatário precisa pedir ao herdeiro a entrega da coisa legada.

O legatário, salvo disposição expressa do testador, não responde pelo pagamento das dívidas do espólio, atribuição dos herdeiros. $\mathrm{O}$ herdeiro responde pelas dividas do de cujus, na proporção do seu quinhão. 
Seguindo a linha de Venosa (2010), o herdeiro toma posse dos bens no ato da abertura da sucessão, por força da aplicação do princípio de Saisine ${ }^{3}$. Por outro lado, o legatário não teria a mesma prerrogativa, devendo aguardar a abertura do testamento, bem como a declaração de sua validade para receber o legado. Além disso, o legatário não responde pelas dívidas do espólio como ocorre com o herdeiro, salvo se houver disposição expressa em sentido contrário, inserida no testamento pelo autor da herança.

A herança, portanto, se difere do legado, sobretudo, porque neste, a "doação" é realizada em testamento, disposição testamentária a título singular, de bem certo e determinado integrante da herança, que só será recebida se houver testamento válido.

A herança, por sua vez, é o conjunto de bens ou o patrimônio deixado por uma pessoa que morreu, cuida-se do montante dos bens e direitos do de cujus, subtraída a meação do cônjuge sobrevivente, que se trata de uma universalidade de bens e direitos que permanecem íntegros e indivisos até a sua individuação pela partilha.

\subsubsection{Sucessão Legítima}

A sucessão, quanto à fonte da qual se origina, pode ser legítima ( $a b$ intestato), ou testamentária, ou seja, dá-se por lei, seguindo a ordem de vocação hereditária ou por ato de disposição de última vontade do autor da herança, respectivamente (artigo 1.786 do Código Civil). Assim, sempre que houver um testamento válido, respeitar-se-á a manifestação de última vontade do falecido, ao passo que, na ausência de testamento ou diante de sua invalidade, seguir-se-á a ordem de vocação legítima, sendo esta devidamente estabelecida na lei.

O atual Direito das Sucessões é resultado da fusão do Direito Romano e do Direito Germânico; o primeiro, com sua absoluta liberdade de testar, abrangendo todo o patrimônio do de cujus, e o Direito Germânico ignorando o testamento, e, por isso, atribuindo a herança aos herdeiros legítimos do falecido.

\footnotetext{
${ }^{3}$ O princípio de Saisine surgiu na Idade Média instituído pelo Direito Francês, sua dicção indica que a herança não pode ficar sem dono, ou seja, a morte do de cujus transmite aos seus sucessores a propriedade e a posse da herança. Segundo Gonçalves (2010, p.35), "a morte, a abertura da sucessão e a transmissão da herança aos herdeiros ocorrem num só momento. Os herdeiros, por essa previsão legal, tornam-se donos da herança ainda que não saibam que o autor da sucessão morreu, ou que a herança lhes foi transmitida. Mas precisam aceitar a herança, bem como repudiá-la, até porque ninguém é herdeiro contra sua vontade".
} 
A sucessão será legítima em caso de inexistência de testamento (ab intestato), ou quando ocorre a anulabilidade ou caducidade (quando faltar o bem-objeto ou destinatário) do mesmo. Em tal espécie de sucessão, a lei determina a ordem de vocação hereditária que será seguida no ato da partilha, devendo ser garantido aos herdeiros necessários - descendentes, ascendentes e cônjuge - metade da herança do de cujus. Seguindo esse entendimento assevera Fiúza (2014, p. 1252):

[...] a sucessão legítima se dá em quatro momentos:

a) quando o de cujus morrer sem testamento;

b) quando o testamento for anulado ou caducar;

c) quando o testador não dispuser da totalidade da herança; deixando parte sem destinação no testamento;

d) quando houver herdeiros necessários, que restrinjam a liberdade de testar à parte disponível. Havendo descendentes, ascendentes ou cônjuge supérstite, ou seja, havendo herdeiros necessários, o testador só poderá dispor da metade de seu patrimônio. A outra metade deverá obrigatoriamente ser deixada para os herdeiros necessários.

A sucessão legítima é tratada, principalmente, nos artigos 1786, 1788, 1789, 1790, 1829, 1845 e 1846 do Código Civil vigente, tendo como grande referencial, a ordem da vocação hereditária estabelecida no art. 1829 do Código Civil de 2002. Cuida-se da distribuição em classes preferenciais das pessoas chamadas a suceder.

Antes da edição do Código Civil Brasileiro de 1916, a vocação hereditária seguia-se a seguinte ordem: descendentes, ascendentes, colaterais até o décimo grau, cônjuge supérstite e fisco. Com a Lei 1.839/1907 houve a alteração na ordem hereditária, trazendo o cônjuge para o terceiro lugar na linha sucessória e limitando a sucessão dos colaterais ao sexto grau.

Sob a égide do Código Civil de 1916, o cônjuge integrava a ordem de vocação hereditária, ocupando o terceiro lugar, depois dos descendentes e ascendentes, não sendo, todavia, considerado herdeiro necessário, de forma que poderia ser excluído da sucessão pela via testamentária.

No atual Código Civil de 2002, por sua vez, apesar de o cônjuge permanecer em terceiro lugar na ordem de vocação, na realidade, foi elevado à condição de herdeiro necessário (art. 1.845 do CC), sendo-lhe, portanto, assegurado a parte da herança, denomina da legítima. Dessa forma, o cônjuge passou a ter participação concorrente com os herdeiros de primeira classe - descendentes - dependendo do regime de bens adotado no casamento, e também com os herdeiros de segunda classe - ascendentes - independente do regime de bens.

Por outro lado, importa destacar que o cônjuge sobrevivente somente poderá ser beneficiado pela herança, se não estiver separado judicialmente do falecido ou se estiver 
separado de fato há menos de dois anos, ou seja, o legislador retirou o direito à legítima do cônjuge que, comprovadamente, se desvinculou de seu consorte, sendo-lhe permitido, inclusive, constituir uma união estável nessa situação.

$\mathrm{O}$ direito do marido ou da mulher participar na herança do que morrer, não deve ser confundido com regime de bens do casamento. No direito das sucessões, a participação do cônjuge na herança nasce da qualidade de consorte, enquanto que as ressalvas feitas na lei são consequência do regime de bens escolhido pelos cônjuges.

No regime de comunhão universal, tanto os bens que as pessoas tinham antes de casar, como os adquiridos durante o casamento passam a pertencer ao marido e a mulher. No regime de comunhão parcial, com exceção dos bens recebidos por doação e por herança, apenas os bens adquiridos por qualquer dos cônjuges durante o casamento passam a pertencer a ambos.

Vigorando, portanto, ao tempo da morte de um cônjuge o regime de comunhão universal ou de comunhão parcial, o outro cônjuge terá direito à parte dos bens comuns que pertencia ao casal.

\subsubsection{Sucessão testamentária}

A sucessão testamentária é a sucessão que ocorre de acordo com o ato de última vontade, ou seja, de testamento ou codicilo, válido e eficaz. O titular de um patrimônio pode dispor sobre a destinação de seus bens mortis causa, desde que respeitada à parte indisponível se lhe houver herdeiros necessários. A sucessão testamentária pode ser tanto a título universal quanto a título singular.

Rizzardo (1996, p. 203) descreve sobre a origem da palavra testamento: “[...] tem sua origem no verbo latino testari, com o significado de testemunhar. Foi acrescentado o sufixo mentum, do que derivou o substantivo".

Como já mencionado anteriormente, predomina no ordenamento jurídico brasileiro a sucessão legítima, sendo a sucessão testamentária é uma exceção. A sucessão testamentária é limitada pela sucessão legítima, preceitua Monteiro (2003, p.10), “[...] que absoluta não é a liberdade de testar, como outrora sucedia no primitivo direito romano". Atualmente, pelo direito pátrio, se o testador tem herdeiros necessários, ou seja, descendentes, ascendentes e cônjuge (art.1845, CC/02), poderá dispor somente da metade de seus bens (art. 1789, CC/02). 
Havendo, destarte, herdeiros em linha reta, descendente ou ascendente, ou cônjuge sobrevivente, denominados herdeiros necessários, divide-se o universum jus defuncti em duas partes iguais; a legítima, que, de direito, cabe aos referidos herdeiros, e a porção disponível, da qual o testador pode livremente dispor, ou para outorgá-la ao cônjuge sobrevivente, ou a qualquer de seus herdeiros, ou a estranhos. As únicas restrições existentes são ditas pelos arts. 1801 e 1.802 do Código Civil, que regulam a incapacidade testamentária passiva. (MONTEIRO, 2003, p.10).

A sucessão só é permitida por lei ou por testamento, ou seja, no direito sucessório brasileiro não se admite a sucessão contratual. Com fulcro ao art. 426, CC/02, são proibidos os pactos sucessórios, seguindo a lógica de que, "não pode ser objeto de contrato a herança de pessoa viva". (BRASIL, 2002).

Nesse entendimento aduz Monteiro (2003, p. 13):

\begin{abstract}
A lei pátria, em tal questão, mostrou-se fiel à tradição romana; quer se trate de pacto aquisitivo (de sucedendo), impondo-se sua condenação, porque nele se pode lobrigar um votum captandae mortis, que fere a sensibilidade e repugna à consciência jurídica nacional. A expressiva denominação que outrora se lhes atribuiu pacta corvina, evidencia a repulsa provocada por semelhante estipulação.
\end{abstract}

A proibição da sucessão contratual, conforme preceitua o referido art. 426, CC/02, é taxativa, porém a doutrina aponta duas exceções, como Diniz (2002, p. 19) relata:

1) o contrato antenupcial, em que os nubentes podem dispor a respeito da recíproca e futura sucessão, desde que não excedam a metade dos bens (CC, arts. 1.668, IV, 1.655 e 546) e; 2) partilha de bens, entre os descendentes, feita pelos pais por ato inter vivos, pode ser considerada como exceção à norma do art. 426, por corresponder a uma sucessão antecipada, embora apresente inconvenientes, porquanto apenas pode abranger bens presentes.

No extinto Código Civil de 1916, no artigo 314, admitia-se a estipulação, no pacto antenupcial, de doações para depois da morte do doador, o que, no atual Código Civil, não é mais permitido.

\title{
1.2 Abertura da sucessão - Princípio de Saisine
}

Abre-se imediatamente a sucessão com o fim da existência da vida, conforme o artigo $6^{\circ}, \mathrm{CC} / 02$, "A existência da pessoa natural termina com a morte; presume-se esta, quanto aos ausentes, nos casos em que a lei autoriza a abertura de sucessão definitiva".

Assim, devolução ou delação é o oferecimento da herança aos herdeiros ou legatários. É a possibilidade de aceitação da herança no momento em que passa à disposição dos herdeiros estabelecidos em lei ou em testamento. 
O princípio da Saisine sustenta-se na ideia de que o próprio de cujus transmite ao sucessor o domínio e a posse da herança (Le mort saisit le vif). Acolhido no art. 1.784, do Código Civil de 2002, tal princípio harmoniza-se com o art. 1.207, do mesmo diploma, pelo qual o sucessor universal continua detentor do direito à posse do seu antecessor, (art. 1.206, CC/02). (GONÇALVES, 2010).

Droit de Saisine significa "Direito da posse", transmissão da herança dos herdeiros ou legatários. Em consonância ao principio Saisine, verifica-se a capacidade sucessória dos herdeiros e legatários de acordo com a lei em vigor na data da morte do de cujus. (HIRONAKA, 2007).

A posse e o domínio da herança são transmitidos aos herdeiros compulsoriamente sem formalidades, não importando o fato dos herdeiros terem ou não conhecimento da morte do de cujus, ou o fato deles estarem em local incerto. Todo o acervo hereditário, tanto ativo como passivo, é transferido aos herdeiros.

Com efeito, Rodrigues apud Rizzardo (1996, p. 34) preleciona que:

[...] o herdeiro se sub-roga, no que diz respeito à posse da herança, na própria situação que o finado desfrutava. Se era ele titular de uma posse justa e de boa fé, o herdeiro adquirirá uma posse justa e de boa fé, senão, for injusta a posse do de cujus, a posse de seu sucessor terá igual efeito, pois ninguém pode transmitir mais direitos do que tem. É verdade, entretanto, que se a posse for violenta ou clandestina, pode ela convalescer desses vícios, após transcurso de ano e dia a contar da cessação da violência ou da clandestinidade.

Os herdeiros se tornam titulares dos direitos, mas também das obrigações que pertenciam ao de cujus, porém, conforme o (art. 1.792, CC/02) ${ }^{4}$, limitando-se, a responsabilidade pelas dívidas ao ativo hereditário.

\section{Herança}

Do latim haerintia, pertences; posteriormente, herdança, resultando a contração herança. Universalidade dos bens deixado pelo de cujus, patrimônio ativo e passivo deixado pelo defunto. (ACQUAVIVA, 2008, p. 256).

\footnotetext{
${ }^{4}$ Art. 1.792. O herdeiro não responde por encargos superiores às forças da herança; incumbe-lhe, porém, a prova do excesso, salvo se houver inventário que a escuse, demonstrando o valor dos bens herdados. (BRASIL, 2002).
} 
A herança é o objeto da sucessão causa mortis e compreende todo o patrimônio do de cujus, sendo direitos, obrigações, ativo, passivo, e outros, com exceção dos direitos personalíssimos.

Nos termos do art. 1.791 do CC/02, a herança é uma universalidade de direitos indivisíveis até sua efetiva partilha, ficando em condomínio, ou seja, existindo mais de um herdeiro ou legatário, ou ambos, o direito de cada um permanecerá indivisível até que sejam os bens partilhados.

\section{Meação}

Meação é a parte que cabe a cada cônjuge sobre os bens que integram o patrimônio do casal. Acquaviva (2008, p. 315) define meação:

[...] No Direito de Família, mais precisamente no regime de comunhão universal de bens (arts. 1.667 a 1.671 do CC), sendo a propriedade dos bens comum aos cônjuges, havendo separação judicial extingue-se o regime de bens (art 1.576, caput, do CC), recebendo, cada cônjuge, sua meação ou, em caso de morte deste, seus herdeiros. No Direito das Sucessões, meação é a parte que cabe ao cônjuge supérstite (sobrevivente), parte esta que compreende a metade dos bens do acervo. CC: arts. 1.575 e 1.576 , caput.

Para Nicolau (2007, p. 49):

O substantivo meação (derivado do verbo mear) nada mais é do que a simples atribuição dos bens a cada um dos cônjuges que unidos trabalharam (em planos diferentes) para construir o patrimônio que - por ocasião da dissolução da sociedade conjugal - (divórcio, separação judicial, morte e anulação) deverá ser partido ao meio, meado.

Portanto, conforme o regime de bens adotado pelo casal, no casamento existirá ou não a meação. A meação é um direito de família e um direito patrimonial, e não um direito sucessório, pois o que se discute é a divisão dos bens com a dissolução do casamento.

No regime da comunhão universal de bens, a meação do patrimônio de cada cônjuge, inclui todos os bens constituídos pelo casal, tanto na constância do casamento como também aqueles que eram particulares de cada um antes do matrimônio. Não existindo bens particulares, tornam-se bens comuns àqueles adquiridos antes e durante a união.

A meação existirá também no regime da comunhão parcial de bens e na participação final dos aquestos, quando consistirá no direito à propriedade da metade dos bens adquiridos de forma onerosa durante o casamento. 
Nos regimes da separação total de bens e separação obrigatória (legal), não há meação entre os cônjuges, pois os patrimônios não se confundem. Os bens são particulares ao homem e a mulher. Porém, existe exceção à regra, com a aplicabilidade da Súmula 377 do Supremo Tribunal Federal, que determina: "No regime de separação legal de bens, comunicam-se os adquiridos na constância do casamento". (BRASIL, 1964). A Súmula foi editada no tempo em que estava em vigor o Código Civil de 1916, mas, com o novo Código Civil de 2002 a aplicabilidade da referida Súmula ainda ocorre.

\section{Diferença entre meação e herança}

Como já conceituado, herança é todo o patrimônio, direitos e obrigações, deixados pelo de cujus, que caberá aos seus herdeiros; somente a herança será objeto de transmissão causa mortis. A meação, a seu turno, é a divisão dos bens dos cônjuges, quando existe comunicação patrimonial.

Para análise dos casos em que cônjuge terá direito a herança ou a meação é necessário verificar o regime de bens adotados quando do casamento. No extinto Código Civil Brasileiro de 1916, o direito sucessório do cônjuge sobrevivente independia do regime de bens.

Conforme já dito, no vigente Código Civil pátrio, o direito do cônjuge sobrevivente à meação e à herança é avaliado conforme o regime de bens que regulava o casamento. Quando um dos consortes vem a falecer, ocorre a dissolução do matrimônio e, dependendo do regime de bens, uma parte do patrimônio do de cujus é do sobrevivente por direito próprio e não por direito sucessório.

\section{A exclusão sucessória}

\subsection{Indignidade: conceito}

A indignidade é uma pena civil que afasta do direito à herança não só o herdeiro, como também o legatário que cometeu atos criminosos ou reprováveis contra o autor da herança ou a membros de sua família. (DINIZ, 2002). Na definição de Beviláqua (1958) apud Nader (2010, p. 89), “Indignidade é a privação do direito, cominada por lei, a quem cometeu certos atos ofensivos à pessoa ou interesse do hereditando".

Para que o herdeiro ou legatário venha ser condenado à indignidade, depende do enquadramento da conduta imputada em uma das causas elencadas no Código Civil de 2002, in verbis: 
Art. 1.814. São excluídos da sucessão os herdeiros ou legatários:

I - que houverem sido autores, co-autores ou partícipes de homicídio doloso, ou tentativa deste, contra a pessoa de cuja sucessão se tratar, seu cônjuge, companheiro, ascendente ou descendente;

II - que houverem acusado caluniosamente em juízo o autor da herança ou incorrerem em crime contra a sua honra, ou de seu cônjuge ou companheiro;

III - que, por violência ou meios fraudulentos, inibirem ou obstarem o autor da herança de dispor livremente de seus bens por ato de última vontade.

Art. 1.815. A exclusão do herdeiro ou legatário, em qualquer desses casos de indignidade, será declarada por sentença.

Parágrafo único. O direito de demandar a exclusão do herdeiro ou legatário extingue-se em quatro anos, contados da abertura da sucessão. (BRASIL, 2002).

No Código Civil de 1916, a pena da indignidade atingia quem atentasse contra a vida do autor da herança; porém, no Código Civil de 2002 o legislador achou por bem estender a pena também àqueles atentassem contra os parentes em linha reta, o cônjuge e o companheiro do de cujus.

A indignidade ocorre com o trânsito em julgado da sentença declaratória, sendo seus efeitos retroativos ao momento da abertura da sucessão. Logo, o indigno não deverá colher qualquer benefício na herança. Os frutos e rendimentos que dos bens da herança houver eventualmente auferidos devem ser devolvidos ao espólio, resguardado o direito do indigno a ser indenizado das despesas com a conservação do patrimônio (art. 1.817, § único, CC/02).

\subsection{0 reconhecimento judicial na decretação da indignidade sucessória}

A indignidade exposta na lei não opera automaticamente, seu pronunciamento deve se dar por sentença transitada em julgado em ação ordinária. A avaliação da conduta do herdeiro não se faz nos autos do inventário, mas em ação declaratória, no procedimento ordinário.

É parte legítima para a propositura da ação de declaração da indignidade qualquer um dos herdeiros a quem a aplicação da pena beneficie. Na ação de declaração de indignidade, o acusado tem a oportunidade de apresentação da defesa, prevalecendo o princípio da presunção de inocência enquanto não ocorre a sentença definitiva. (NADER, 2010).

Como já referenciado, a ação de declaração de indignidade não é espontânea, é necessário que seja provocado o poder judiciário. O prazo decadencial para seu ajuizamento é de quatro anos, contados a partir da abertura da sucessão (art. 1.815, § único).

Há de se ressaltar que existe um Projeto de Lei no 7806/2010, proposto pela Senadora Serys Slhessarenko, que torna espontânea a exclusão de herdeiro ou legatário indigno que seja condenado por sentença penal transitada em julgado. $O$ fato da indignidade não ser 
automática, acaba possibilitando ao herdeiro indigno acessar a herança, caso outro herdeiro não se manifeste para a propositura da ação declaratória de indignidade. Assim, se nenhum interessado pleiteasse a exclusão do indigno, não ocorreria à exclusão do herdeiro, ainda que a sua culpa seja pelo homicídio do autor da herança.

Para evitar tal injustiça, defende-se a legitimidade do Ministério Público para o ajuizamento da ação de indignidade. A esse respeito, importa registrar que foi aprovado na I Jornada de Direito Civil o Enunciado 116, reconhecendo ao Ministério Público legitimidade para propor ação declaratória de indignidade, desde que presente o interesse público. (NADER, 2010).

Não há como ignorar que o Estado pode ser interessado na herança quando não houver demais herdeiros, ou até mesmo quando aquele que poderia ajuizar ação de declaração de indignidade não tem capacidade civil dentro do prazo da propositura da ação.

O Ministério Público, portanto, não só pode como deve intervir em caso de indignidade, de forma a garantir a defesa da ordem jurídica e os interesses sociais e individuais indisponíveis, na formado art. 127, Constituição da República de 1988. Isso porque, se assim não o fizer, poderá deixar impune aquele que, de forma ilícita, herdou patrimônio através do homicídio do autor da herança.

\subsection{Efeitos da indignidade}

Os efeitos da exclusão sucessória são pessoais, não passam de uma pessoa para outra. Os descendentes do herdeiro excluído sucedem por representação ou por estirpe, como se ele morto fosse antes mesmo da abertura da sucessão (art. 1.816, CC/02). Se ocorrer a premoriência dos representantes do indigno, este ficará excluído da sucessão dos bens adquiridos por representação. $\mathrm{O}$ indigno não aproveitará nem eventualmente aqueles bens que ele foi excluído (art. 1.816, § único, CC/02).

O ajuizamento da ação de exclusão sucessória independe da prévia condenação penal, existindo a possibilidade da prova da indignidade ser produzida no juízo cível. Porém, se o indigno for absolvido na esfera criminal por não existir a materialidade do crime ou pela excludente de ilicitude, não será possível a apreciação no juízo civil.

A primeira consequência da decretação da sentença declaratória de indignidade transitada em julgado é a perda do direito sucessório. Com a abertura da sucessão automaticamente é transmitido o direito de propriedade e posse indireta aos herdeiros (art. 
1.784, CC/02), depois se tem o direito de aceitação ou renúncia da herança (art. 1.804 e seguintes, CC/02). A transmissão da herança com a abertura da sucessão se dá a todos os herdeiros, inclusive o indigno, que perderá o seu direito com a sentença que assim o declara.

Se o indigno recebeu algum bem em vida pelo autor da herança, considera-se adiantamento da herança e tal liberalidade não é revogada com a indignação. Assim, “[...] $\mathrm{O}$ art. 2008 do Código Civil não deixa margem de dúvida, pois apenas exige a conferência das doações, a fim de se apurar eventual excesso em relação à parte disponível da herança e devolução do valor sobejante". (NADER, 2010, p. 102).

Como já mencionado, o herdeiro declarado indigno por sentença é obrigado a devolver os frutos e rendimentos da herança que recebeu. Por força do efeito ex tunc da sentença da declaração de indignidade, a devolução deverá ser feita desde abertura da sucessão, resguardado o direito de reembolso das despesas a conservação dos frutos e rendimentos auferidos (art. 1.817, § único, CC/02).

Será herdeiro aparente aquele que ainda não foi julgado como herdeiro indigno, sendo permitido o exercício dos direitos que lhe são atribuídos, inclusive o direito de alienações onerosas do patrimônio hereditário a terceiros de boa-fé.

Os atos de administração e alienações feitas pelo indigno antes da sentença da indignidade são válidos. Porém, diante de eventuais prejuízos causados aos herdeiros deverá o indigno ressarci-los. Comprovado o ato ilícito, com todos os seus elementos, caberá às vítimas o direito de demandar-lhe perdas e danos (art. 1.817, caput, CC/02).

Os efeitos da pena de indignidade são personalíssimos, cabendo somente à exclusão do direito ao usufruto ou à administração dos bens que a seus sucessores couberem na herança (art. 1816, § único, do Código Civil Brasileiro). O indigno não deixará de ter direito ao usufruto legal, à administração ou o direito a eventual herança diversa de seus descendentes, relativos ao patrimônio hereditário que não se trata da exclusão e que pertençam a seus herdeiros a título diverso. (VENOSA, 2010).

A propósito, se o herdeiro indigno tiver matado o próprio pai ou a mãe, sendo o indigno único filho, os filhos deste herdarão por direito próprio e não por representação. Porém, se o de cujus tiver outros filhos além do indigno, os filhos deste herdarão por representação. (NADER, 2010).

Um caso de grande repercussão e repúdio da sociedade foi o crime de parricídio e matricídio cometido por Suzane Loise Von Richthofen. No dia 31 de outubro de 2002, ela, 
seu namorado, Daniel Cravinhos de Paula e Silva, e o irmão deste, Cristian Cravinhos de Paula e Silva, executaram friamente os pais de Suzane. (CASTRO, 2017).

Os pais de Suzane tinham outro filho além dela, Andreas Albert Von Richthofen, que, na ocasião, ajuizou uma ação de exclusão de herança para que a irmã não lograsse êxito em ficar com a herança fruto do assassinato dos próprios pais.

Em 2015, Suzane Loise Von Richthofen foi considerada indigna, por sentença transitada em julgado, tendo sido excluída da herança de seus pais Manfred e Marísia Von Richthofen, e, como não tem filhos para herdar por representação, o patrimônio hereditário ficou para Andreas Albert Von Richthofen, irmão de Suzane.

\title{
5.4 Reabilitação do indigno
}

A reabilitação do indigno ocorrerá se o autor da herança o perdoar por ato autêntico (escritura pública), ou por testamento (art. 1.818, CC/02). Sobre o assunto, Nader (2010, p. 105) aduz:

\begin{abstract}
Nada justifica o desvio de conduta do indigno. Qualquer que tenha sido a sua prática, esta é condenável nas esferas da Moral e do Direito. A deslealdade, a agressão física, o ataque à honra provocam a revolta da vítima e a repulsa de quem tem sensibilidade ética. Somente os espíritos nobres possuem a capacidade para o perdão. Isto ocorreu com Sua Santidade o Papa João Paulo II ao perdoar Mehmet Ali Agca, que tentou matá-lo em 1981. .
\end{abstract}

Se o autor da herança perdoou o indigno, significa que ele não deseja a efetivação da aplicação da pena de exclusão sucessória. A sentença da indignidade exclui o herdeiro da sucessão e o perdão o reabilita, de forma que exclui os efeitos da pena que lhe foi apregoada em juízo.

De par com isso, se aquele que tem interesse legítimo na sucessão não propor ação declaratória de indignidade no prazo decadencial de quatro anos, presume-se perdoado o indigno, contudo, não há se falar em reabilitação nesse caso, pois não houve a condenação com a pena civil de indignidade.

$\mathrm{O}$ ato de perdoar, gerando a reabilitação do indigno, é direito privativo e formal do ofendido. Este, além de ser titular do patrimônio, é o que pode avaliar o grau da ofensa e o mérito do perdão. "Não havendo reabilitação expressa, o indigno, contemplado em testamento do ofendido, quando o testador, ao testar, já conhecia a causa da indignidade, pode suceder no limite da disposição testamentária (art. 1.818, § único, CC/02)”. (DINIZ, 2002, p. 53). A 
autora ainda conceitua o referido artigo: "Trata-se da reabilitação de indigno tácita, por ser curial que o está perdoando [...]”. (DINIZ, 2002, p. 53).

Nader (2010) entende que não existe a reabilitação tácita e ainda leciona que caracterizar o art. 1.818, § único, $\mathrm{CC} / 02$ como existência de tal reabilitação, é uma forma equivocada de interpretação. Leia-se:

\begin{abstract}
Inexiste a reabilitação tácita. Ainda que o ofendido, por suas atitudes, revele haver perdoado o indigno, tal comportamento não poderá ser interpretado juridicamente como reabilitação, pois esta somente se caracteriza quando expressa. A hipótese prevista no parágrafo único do art. 1.818 não a configura, apenas garante os efeitos da cláusula testamentária em que o hereditando, ciente da causa de indignidade, beneficia o indigno. Não obstante, Pires de Lima e Antunes Varela nomeiam esta iniciativa do hereditando por reabilitação limitada, tácita ou indireta, terminologia imprópria e com potencial de gerar dúvidas. Casati e Russo incidem, igualmente, no equívoco. (CASATI; RUSSO, 1950 apud NADER, 2010, p.107, grifos do autor).
\end{abstract}

Monteiro (2003, p. 68) posiciona-se sobre o assunto de forma categórica: "Não existe perdão tácito ou presumido, nem pode ser concedido oralmente, ou por instrumento particular despido de autenticidade". Entre os autores pesquisados no presente trabalho, a maioria absoluta leciona de forma a existir a reabilitação tácita, configurada no art. 1.818, § único, do $\mathrm{CC} / 02$

No entanto, como o próprio caput do mencionado artigo determina, a reabilitação deve se dar de forma expressa em testamento ou em outro ato autêntico. Ressalta-se que não existe reabilitação diversa da expressa e nem existe o perdão tácito por parte do ofendido. Se o autor da herança já conhecia a causa da indignidade e ainda assim contempla em testamento o indigno, não significa que o ofendido o perdoou, apenas que o indigno está autorizado a suceder no limite que permite a disposição testamentária.

A reabilitação é irretratável, porém, se comprovado que o autor da herança praticou o ato do perdão alheio a sua vontade, de forma que foi coagido, será passível de anulação. Se o testamento for revogado e contiver a cláusula de reabilitação, esta será conservada. Esse entendimento não é taxativo, existem opiniões diversas sobre o assunto. (PEREIRA, 2015).

\title{
5.5 Diferença entre indignidade e deserdação
}

Não obstante às diferenças existentes entre indignidade e deserdação, em ambos os casos surgem à quebra do dever de gratidão, acarretando a perda do direito à sucessão. São sanções civis aplicáveis àqueles que não se comportaram bem com o autor da herança. 
A deserdação é o ato pelo qual o titular da herança exclui da sucessão o herdeiro necessário, mediante testamento com expressa declaração da causa, privando-o de sua legítima, por ter praticado qualquer ato enumerado nos artigos 1.814, 1.962 e 1.963 do Código Civil de $2002^{5}$.

A indignidade não se confunde com a deserdação, embora ambas tenham a mesma finalidade, qual seja, punir com a exclusão o herdeiro ou o legatário que praticar atos contra o autor da herança.

Enquanto a indignidade é ato reconhecido mediante uma ação de indignidade, nos termos do art. 1.815 do Código Civil, a deserdação se manifesta, exclusivamente, por ato de vontade do autor da herança (testamento). Qualquer sucessor (legítimo ou testamentário) pode ser indigno, contudo, somente o herdeiro necessário pode ser deserdado.

A indignidade é solicitada por terceiros interessados ou pelo Ministério Público, quando há interesse público, no prazo de quatro anos da abertura da sucessão, e decretada mediante sentença transitada em julgado.

A deserdação é feita somente por testamento e após a abertura da sucessão, logo, impossível deserdar algum herdeiro antes da morte do autor da herança, conforme determina o Código Civil Brasileiro de 2002.

Outro aspecto importante é que a reabilitação do indigno ocorrerá se o autor da herança o perdoar por ato autêntico (escritura pública), ou por testamento (art. 1.818, CC/02),

\footnotetext{
${ }^{5}$ Art. 1.814. São excluídos da sucessão os herdeiros ou legatários:

I - que houverem sido autores, co-autores ou partícipes de homicídio doloso, ou tentativa deste, contra a pessoa de cuja sucessão se tratar, seu cônjuge, companheiro, ascendente ou descendente;

II - que houverem acusado caluniosamente em juízo o autor da herança ou incorrerem em crime contra a sua honra, ou de seu cônjuge ou companheiro;

III - que, por violência ou meios fraudulentos, inibirem ou obstarem o autor da herança de dispor livremente de seus bens por ato de última vontade.

[...] 1.962. Além das causas mencionadas no art. 1.814, autorizam a deserdação dos descendentes por seus ascendentes:

I - ofensa física;

II - injúria grave;

III - relações ilícitas com a madrasta ou com o padrasto;

IV - desamparo do ascendente em alienação mental ou grave enfermidade.

Art. 1.963. Além das causas enumeradas no art. 1.814, autorizam a deserdação dos ascendentes pelos descendentes:

I - ofensa física;

II - injúria grave;

III - relações ilícitas com a mulher ou companheira do filho ou a do neto, ou com o marido ou companheiro da filha ou o da neta;

IV - desamparo do filho ou neto com deficiência mental ou grave enfermidade. (BRASIL, 2002).
} 
ao passo que, na deserdação, o testador só poderá perdoar o deserdado, por meio de revogação testamentária.

Como se pode observar, portanto, são muitas as diferenças entre deserdação e indignidade, passando-se, nesse momento, ao tema central do artigo relacionado ao cônjuge que comete homicídio com o objetivo espúrio de obter a sua meação de forma instantânea e ilícita.

\section{0 cônjuge que comete homicídio doloso e a possibilidade de afastamento da meação por meio da declaração de indignidade: sugestão de alteração legislativa}

Conforme já referenciado, meação não se confunde com herança. Esta é decorrente do direito sucessório, em que o patrimônio do de cujus é transmitido aos seus herdeiros legítimos ou testamentários, ao passo que a meação é proveniente do direito de família e decorre da partilha dos bens que compõem o conjunto patrimonial comunicável, quando da dissolução do casamento.

A indignidade é uma pena civil. Mesmo que o cônjuge ofensor tenha que arcar com as sanções penais advindas de sua condenação, também deverá ser aplicada a penalidade civil, quando presente a comprovação de algum ato que dê causa a sua indignidade.

Os crimes que dão causa à indignidade são: a atuação do herdeiro como autor, coautor ou partícipe de homicídio doloso, ou tentativa deste, contra a pessoa de cuja sucessão se tratar, seu cônjuge, companheiro, ascendente ou descendente; a ação do herdeiro no sentido de acusar caluniosamente em juízo o autor da herança ou incorrerem em crime contra a sua honra, ou de seu cônjuge ou companheiro; a conduta do herdeiro que, por violência ou meios fraudulentos, inibir ou obstar o autor da herança de dispor livremente de seus bens por ato de última vontade (art. 1.814, CC/02). Entre todos esses crimes o que causa maior repulsa na sociedade é o crime doloso.

A regra, no Brasil, é que a indignidade exclui o direito à herança e não a meação. Conforme a jurisprudência brasileira o art. 1.814, CC/02 é rol taxativo: 
EMENTA: DIREITO DE SUCESSÕES - EXCLUSÃO DA SUCESSÃO HERDEIRO - HOMICÍDIO DOLOSO PRATICADO CONTRA CÔNJUGE POSSIBILIDADE - EXCLUSÃO DA MEAÇÃO - IMPOSSIBILIDADE. 1 - Podem ser excluídos da sucessão por indignidade os herdeiros e legatários, "ex vi" do art.1.814do Código Civil. 2 - A meação pertence ao cônjuge por direito próprio, sendo inviável, portanto, a extensão da pena de exclusão do cônjuge herdeiro, em razão de indignidade (art.1.814, inc.I, doCódigo Civil), ao direito do réu, decorrente do regime de bens adotado no casamento. 3 - Recurso parcialmente provido. TJMG. 9572648-72.2008.8.13.0024. Relator: Des.(a) EDGARD PENNA AMORIM. Relator do Acórdão: Des.(a) EDGARD PENNA AMORIM. Data do Julgamento: 22/07/2010. (Data da Publicação: 29/10/2010).

Contudo, o entendimento, de que não cabe a exclusão do cônjuge indigno da meação, na realidade, gera injustiças e até motivação para a prática do crime de homicídio doloso contra o cônjuge. O que se vê, na realidade, é que a doutrina, numa visão simplista, analisa normalmente se o cônjuge é meeiro ou herdeiro, não levando em consideração se o cônjuge indigno acresceu ao seu patrimônio a meação, unicamente, porque praticou homicídio contra o autor da herança.

Por mais que a maioria dos juristas, nesses casos, analise taxativamente o que é determinado em lei, sem considerar o caso concreto, entende-se que há possibilidade de aplicação da analogia, dos costumes e o princípio da justiça, como forma de evitar a disseminação de condutas homicidas em busca da meação, senão vejamos:

Ementa: MEAÇÃO. DIVÓRCIO. INDIGNIDADE. QUEM MATOU O AUTOR DA HERANÇA FICA EXCLUÍDO DA SUCESSÃO. ESTE É O PRINCÍPIO CONSAGRADO NO INC. I DO ART. 1595 DO CC, QUE REVELA A REPULSA DO LEGISLADOR EM CONTEMPLAR COM DIREITO SUCESSÓRIO QUEM ATENTA CONTRA A VIDA DE ALGUÉM, REJEITANDO APOSSIBILIDADE DE QUE, QUEM ASSIM AGE, VENHA A SER BENEFICIADO COM SEU ATO. ESTA NORMA JURÍDICA DE ELEVADO TEOR MORAL DEVE SER RESPEITADA AINDA QUE O AUTOR DO DELITO NÃO SEJA HERDEIRO LEGÍTIMO. TENDO O GENRO ASSASSINADO O SOGRO, NÃO FAZ JUS AO ACERVO PATRIMONIAL DECORRENTE DA ABERTURA DA SUCESSÃO. MESMO QUANDO DO DIVÓRCIO, E AINDA QUE O REGIME DO CASAMENTO SEJA O DA COMUNHÃO DE BENS, NÃO PODE O VARÃO RECEBER A MEAÇÃO CONSTITUÍDA DOS BENS PERCEBIDOS POR HERANÇA. APELO PROVIDO POR MAIORIA, VENCIDO O RELATOR. (SEGREDO DE JUSTICA) (Apelação Cível No 70005798004, Sétima Câmara Cível, Tribunal de Justiça do RS, Relator: Luiz Felipe Brasil Santos, Julgado em 09/04/2003). (DIAS, 2017, grifo nosso).

Utilizando subsídio, a decisão da apelação supracitada, serão analisados os fundamentos doutrinários e jurisprudenciais que serviram de embasamento para o voto de cada desembargador, com ênfase na possibilidade de afastamento da meação, por meio da 
declaração de indignidade do cônjuge que comete homicídio doloso contra o autor da herança, ou um familiar deste. Analisa-se:

\section{Voto do Desembargador Luiz Felipe Brasil Santos (Relator)}

[...] Ocorre que o fundamento da apelante para ver seu ex-marido excluído da partilha na ação de divórcio (processo $\mathrm{n}^{\circ} 11488$ - autos em apenso), não encontra respaldo legal, eis que pretende aplicar, por analogia, o art. 1595, inc. I, do CC.

Como bem afirmou o decisum, “(...) Os bens devem ser partilhados entre os cônjuges, pois casados sob o regime da comunhão universal de bens (art. 262, do Código Civil), não estando a hipótese dos autos (homicídio do sogro) elencadas no art. 263, do Código Civil, que estabelece os casos de exclusão da comunhão. Também não há como acolher eventual aplicação analógica do art. 1.595, inciso I, do diploma legal supra mencionado, porque o referido não é herdeiro da vítima do homicídio, como já reconhecido em sentenças anteriores, faltando o requisito da semelhança essencial dos casos postos em análise. Ademais, não se admite analogia para restringir direitos ou quando a enumeração legal é taxativa. Nesse sentido, a lição de Carlos Maximiliano na obra 'Hermenêutica e Aplicação do Direito” (Rio de Janeiro, Forense, 1992, $12^{a}$ ed., p. 213): 'Quando o texto contém uma enumeração de casos, cumpre distinguir: se ela é taxativa, não há lugar para o processo analógico; se exemplificativa apenas, dá-se o contrário, não se presume restringida a faculdade do aplicador do Direito'.

Ademais, cabe frisar que a doutrina estrangeira trazida pela apelante em sua inicial, com o fito de utilizar-se do direito comparado nos remete aos casos específicos de herdeiros excluídos da partilha pois atentaram contra a vida do autor da herança.

A legislação ora sob foco traz uma sanção - exclusão da herança - aos que tentaram ou participaram de tentativa contra a vida daqueles de cuja sucessão se tratar. Em outros termos, como frisou o Ministério Público (fls. 543/549), quis a lei que a regra da indignidade recaísse tão-só naqueles possuidores de laços de sangue elou de extrema afeição com o autor da herança, a ponto de serem penalizados por atos atentatórios a sua vida, honra ou liberdade.

Neste sentido, DESPROVEJO o apelo. (DIAS, 2017, grifo do autor).

Vê-se, pois, que ainda que o cônjuge indigno não seja herdeiro necessário e nem testamentário do sogro, com a prática do crime de homicídio doloso contra este; o indigno há de se beneficiar, de forma ilícita, com a dissolução do seu casamento. O mesmo se dá se a herdeira vier a falecer e não tiver descendentes e nem ascendentes, o cônjuge sobrevivente herdará todo o patrimônio se este não for sentenciado com a pena de indignidade.

O Código Civil de 2002 estendeu a pena da exclusão por indignidade às hipóteses de homicídio doloso, consumado, ou tentado, não só contra o autor da herança, mas também, contra o cônjuge, companheiro, descendente ou ascendente do mesmo.

O voto do Desembargador Luiz Felipe Brasil Santos, já citado, só considerou a lei de forma categórica, sem ponderar os princípios e os costumes. Se ele decidisse em desfavor do indigno, o desembargador não iria contra o que determina a lei, pois o direito à meação é lícito, mas, o recebimento do patrimônio, fruto do homicídio do próprio sogro, pelo indigno não o é. 
A questão da indignidade é pautada na moral, na ética, na equidade, logo, há de se repugnar aquele que extrai vantagem do patrimônio de pessoa a quem ofendeu ou a quem matou, sobretudo, por contrariar o princípio da justiça, valor e a qualidade que as condutas humanas devem assumir no âmbito das suas relações sociais. Cuida-se de princípio básico que objetiva manter a ordem social, valor ideal que constitui a razão de ser o direito, preocupação de todos os sistemas jurídicos, no sentido de alcançar e integrar o ordenamento jurídico de cada país.

Este princípio tem sido utilizado ao longo da história com diferentes sentidos: Sobre o último julgado que foi citado, passa-se analisar o voto da Desembargadora Maria Berenice Dias:

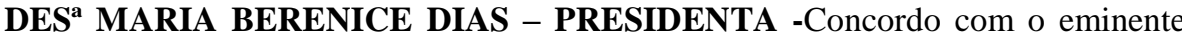
Relator quando diz que o Código Civil de 1916 não previu, entre as hipóteses de exclusão elencadas no art. 1.595 , a situação ora vertida nos autos, uma vez que excluiu da sucessão, exclusivamente, os herdeiros.

No entanto, não vejo como se possa afastar o princípio que regeu a edição dessa regra jurídica de elevado teor moral; No momento em que o legislador revelou a repulsa em contemplar com direito sucessório quem atentar contra a vida do autor da herança, a ponto de excluir o herdeiro da sucessão, nitidamente, rejeitou a possibilidade de que, quem assim age, ser beneficiado com seu ato.

Houve uma omissão do legislador em não prever que tal ato, praticado por outrem, mas que direta ou indiretamente poderia se beneficiar do acervo patrimonial do de cujus, estaria o mesmo sujeito à mesma sanção. No entanto, ao contrário do posto no parecer ministerial, não vejo que a referência exclusivamente ao herdeiro vise punir só quem tivesse laços de sangue ou laços de afinidade com a pessoa contra quem atentou. Não. O legislador quis punir o autor do ato criminoso não lhe dando a herança, ou seja, lhe subtraindo o patrimônio que poderia vir a fazer jus.

Não se pode olvidar que não há plenitude do ordenamento jurídico, prova disso é que, modo expresso, tanto o art. $4^{\circ}$ da Lei de Introdução ao Código Civil quanto o art. 126 do Código de Processo Civil determinam que a Justiça aprecie todas as questões que lhe são postas. Em havendo omissão da lei, por evidente que a solução não é negar a pretensão, pois a própria lei dá o caminho: analogia, costumes e princípios gerais do direito. A lei não permite que seja premiado com a herança quem age contra a vida de alguém, tanto que o pune com a exclusa do direito sucessório. Ora, o fato de o ora apelado não ser herdeiro, mas marido da herdeira, bem como não se estar em sede de sucessão mas frente a ação de divórcio, não se pode afastar a diretriz do legislador e impedir que quem deu ensejo à abertura da sucessão seja contemplado com os bens do de cujus que passou a integrar o patrimônio do casal.

Esta omissão do legislador não se verifica no novo Código, que, no art. 1.814, amplia as hipóteses de exclusão, ao dizer que são excluídos da sucessão os herdeiros ou legatários que houverem sido autores, co-autores ou partícipes de homicídio doloso, ou tentativa desta, contra a pessoa de cuja sucessão se tratar, seu cônjuge, companheiro, ascendente ou descendente.

Ainda que in casu não se possa aplicar o novo Código, cabível atentar que essa ampliação do dispositivo revela a aceitação da diretriz sinalizada pela doutrina.

Confesso que tenho enorme dificuldade em fazer distinguir nos elencos legais se o rol é enumerativo, taxativo ou exemplificativo. No momento em que a lei prevê hipóteses - ainda que hipóteses de exclusão - nunca se pode ter o mesmo como 
exaustivo, porque, às vezes a imaginação - ou a crueldade do ser humano, como no caso - vai além da previsão do legislador.

No entanto, se há omissões na identificação das pessoas integrantes do suporte fático, de tal omissão não se ressentem os princípios, que devem sempre ser identificados para serem invocados quando se verifica uma lacuna na lei. Assim, se há omissão de norma legal, deve sempre que prevalecer o princípio consagrado pelo legislador que, indiscutivelmente, é o de não permitir a quem atenta contra a vida de outrem possa dele receber alguma coisa, seja como sucessor, seja como cônjuge ou companheiro do sucessor, Essa é a intenção do legislador e a função da Justiça é exatamente fazer incidir a orientação ditada pela lei. Aliás, para isso é que somos juízes, para fazer justiça segundo os princípios que regem o sistema jurídico. Não somos, como dizia Montesquieu: labouche de laloi, juízes que simplesmente se limitam a repetir e aplicar a norma contida no elenco legal, permitindo que se conviva com a injustiça. Somos Juízes de Direito, integramos um Tribunal de Justiça.

Confesso que fere meu senso de justiça fazer uma injustiça dessa ordem. No dia em que tomei posse como magistrada, jurei fazer justiça, não aplicar a lei de forma mecânica e casuísta. Se para isso, quem sabe, tiver que afrontar a lei, a dar ensejo talvez de ser acusada de ter me tornado adepto da nominada "justiça alternativa", paciência. Se for esse a qualificativo que mereço, vou aceitar, mas não posso permitir é o locupletamento de alguém com a própria torpeza.

Rogando vênia ao eminente Relator, voto pelo acolhimento do recurso com a inversão dos encargos sucumbenciais para afastar a possibilidade de o apelado se beneficiar da meação que é integrada pela herança da pessoa que ele matou. (DIAS, 2017, grifo nosso).

Como se observa, ainda que exista lei que autorize a perda do direito à meação do cônjuge indigno, o inteligente posicionamento da Desembargadora fez com que a aplicação da lei não se mostrasse um direito engessado e meramente posto.

Considerando-se que o sistema jurídico não é completo, mas sim recheado de lacunas, imperiosa se mostra a interpretação de acordo com a juridicidade, ou seja, a observância dos princípios constantes no ordenamento brasileiro.

Nesse contexto, não se olvida que a lei garante o direito à meação, assim como o direito à vida e à dignidade da pessoa humana. Todavia, se aquele que se utiliza meios criminosos para obter qualquer tipo de bem patrimonial for responsabilizado apenas criminalmente, a justiça não será de fato aplicada. Ora, nem tudo que é lícito é justo ou honesto.

Existe, in casu, a problemática envolvendo a dúvida se o direito à meação deve subsistir à decretação da indignidade, independentemente do meio que foi utilizado para receber esses direitos, ou se deve ser punido aquele que se enriquece de forma ilícita. Aceitar isso é o mesmo que dizer que é crime matar alguém, mas beneficiar-se desse ato não é. Estáse, então, diante de uma antinomia quando se percebe que coexistem, ao mesmo tempo, no 
mesmo sistema jurídico, uma norma proibitória de um determinado comportamento quanto àquela que permite o mesmo ato que foi proibido.

A inexistência de norma legal que determine a perda do direito à meação, diante da prática do homicídio doloso do seu consorte ou um familiar do mesmo, não pode obstar que o juiz julgue sob a luz da analogia, dos costumes e princípios gerais do direito. Tem-se, então, que não é correto afirmar que o artigo $1.814 \mathrm{CC} / 02$ traz um rol taxativo, pois nele não se encerram todas as possibilidades da aplicação da indignidade no caso concreto.

O dogma da completude, ou seja, aquele princípio que o ordenamento jurídico é completo para fornecer ao juiz uma solução para cada caso, sem a necessidade de buscar os princípios, os usos e costumes, a analogia e a equidade, não tem prevalência nas leis pátrias, certamente por existir lacunas no Direito.

Sobre esse entendimento Bobbio (2007, p. 279, grifo nosso) aduz que:

[...] não só nos parece impossível excluir as lacunas, em contraste com a teoria da norma geral exclusiva, mas o próprio conceito de lacuna foi se tornando preciso: a lacuna se verifica não pela ausência de uma norma expressa para a regulamentação de um determinado caso, mas pela ausência de um critério para a escolha de qual das duas regras gerais, aquela exclusiva e aquela inclusiva, deve ser aplicada.

A ausência de um ordenamento jurídico completo sempre vai existir, mas, o que não pode existir é a falta da aplicação da lei ou a ineficácia dela.

Em estudo do último voto do desembargador sobre a apelação do pedido de indignidade e da exclusão da meação, diante do crime cometido pelo genro, que matou o sogro para aumentar o seu patrimônio, leia-se:

\section{DES. JOSÉ CARLOS TEIXEIRA GIORGIS}

[...] Considerando que se trata de uma longa causa, que há tempo se debate, e estando já decidido, a mim também instigou, desde o início, a injustiça dessa situação. É verdade que as hipóteses de indignidade, como também ocorre com as hipóteses de deserdação, são estritamente nominadas no Código Civil, tanto no Código de 1916, como no Código em vigor. É que o legislador, como disse a eminente Revisora e eminente Presidente, não pode cogitar de todas as hipóteses e, portanto, o decisor, na sua tomada de posição, deve considerar, naqueles casos omissos, os aspectos éticos, relevantes, morais, juntamente com os fundamentos legais. [...]

Não há por que, lá como aqui, deixar-se de divisar, no caso concreto, a aplicação do princípio ético, do princípio do senso comum, do princípio da equidade, ancorado nos princípios gerais do Direito, já que a aplicação da analogia é dificultada, podendo-se utilizar os princípios do Direito e dos costumes.

$\mathrm{Na}$ obra de Orlando Gomes, arrola-se que, entre as hipóteses de indignidade, está o fato de o herdeiro ser o autor ou co-autor de homicídio. Arnaldo Rizzardo, em sua obra "Direito das Sucessões", traz uma citação do doutrinador Argentino Horacio e Cejas, afirmando que seria contrário a todo o princípio da justiça que aquele que ofendeu gravemente o causante ou sua memória, que tentou contra sua vida ou terminou com ela, pudesse a vir beneficiar-se com seus bens. 
Então, é o sentido que adoto, aceitando a tese sustentada da tribuna de que o meeiro não deixa de ser um legatário ex legis; portanto, aplicando-se também a indignidade no caso da sucessão legítima, pode-se construir uma nova hipótese de que ali se incluem também outras pessoas que, aproveitando-se diretamente do resultado do seu inexplicável gesto, venham a matar os autores da herança.

Observe-se que já houve até trânsito em julgado da sentença condenatória, tanto que a pena está sendo cumprida; poderia prever-se que a família ajuizasse ação de indenização baseada na sentença transita em julgado e que no final pudesse até, quem sabe, haver-se da penhora desses bens, mas isso ofende o senso comum, a moral do cidadão e a justiça.

Daí rogo vênia ao eminente Relator para dissentir de seu voto e, como a eminente Presidente, estou dando também provimento à apelação. (DIAS, 2017, grifo nosso).

Diante da lacuna legislativa em relação à perda do direito à meação do cônjuge indigno, sugere-se a interpretação analógica dos efeitos da indignidade, a ser definida no caso concreto, quando restar comprovada a intenção do cônjuge sobrevivente de terminar com a vida com consorte, em busca da meação. A indignidade, em primeiro momento, não exclui o direito à meação, pois este se trata de um direito próprio. Contudo, há de se verificar se o recebimento da meação foi fruto de um ato criminoso - homicídio em face de seu consorte, levando a efeito se realmente o cônjuge faz jus a ela.

Outra rara exceção é o julgado a seguir, em que o próprio autor da herança, que vivia em união estável, ajuizou uma ação declaratória de indignidade contra a ex-companheira:

APELAÇÃO CÍVEL - DIREITO DE SUCESSÕES - AÇÃO DE INDIGNIDADE EXISTÊNCIA DE UNIÃO ESTÁVEL ENTRE O AUTOR E A RÉ - EXCOMPANHEIRA - AUSÊNCIA DE HERDEIROS NECESSÁRIOS - LACUNA LEGISLATIVA - POSSIBILIDADE JURÍDICA DO PEDIDO - RECURSO PROVIDO - SENTENÇA ANULADA. (TJ-MS, Relator: Des. Dorival Renato Pavan, Data de Julgamento: 11/09/2008, 5 Turma Cível). (DIAS, 2017).

Ciente da inexistência de lei específica para cada caso concreto, ao juiz cumpre proferir uma sentença, a fim de garantir o cumprimento da ordem social e o interesse coletivo e individual, ainda que contrária à lei.

Com a alteração do conceito de família, que recebeu a proteção constitucional, em qualquer de suas formas, os direitos das famílias e das sucessões, na sua forma positivada, tornaram-se, em muitos pontos, obsoletos.

A sociedade contemporânea é complexa, mutante, e, nessa toada, proferir decisões jurídicas baseadas somente em leis retrógradas significa ignorar as mutações da cultura e das necessidades sociais. Manter-se inerte diante de tantas transformações acarreta o colapso na segurança jurídica, provocando, de forma irresponsável, a incompatibilidade da atividade jurisdicional, que está atrelada em solucionar os litígios existentes. 
Em sendo assim, a fim de preencher tantas lacunas no direito sucessório, defende-se a aplicação do princípio de justiça como forma de excluir do cônjuge indigno o direito à meação, sempre que restar comprovado o crime de homicídio doloso ou a tentativa deste, contra o autor da herança, ou contra o seu descendente ou ascendente.

De par com isso, mostra-se imperiosa a alteração legislativa para reconhecer a legitimidade do Ministério Público para ajuizar ação declaratória de indignidade, bem como para determinar que o cônjuge indigno seja excluído da sucessão, bem como não tenha direito à meação, especialmente, quando comprovado homicídio doloso ou tentativa contra o titular da herança.

\section{Considerações finais}

$\mathrm{O}$ artigo que aqui se encerra buscou tratar da indignidade do herdeiro, assunto inserido no Direito Sucessório brasileiro, tão presente na realidade do país.

Avaliou-se a possibilidade da aplicação, analógica, das consequências da decretação da indignidade, como forma de afastar o cônjuge indigno do seu direito à meação, quando aquele atentar contra a vida do autor da herança a fim de ver acrescido seu patrimônio.

Observou-se que meação e herança são institutos distintos, sendo o primeiro atinente ao regime de casamento escolhido pelo casal e a segunda, do âmbito sucessório. Detalhou-se que, desde o advento do Código Civil de 2002, o cônjuge foi elevado à condição de herdeiro necessário, o que dificulta sua deserdação, uma vez que esta depende da manifestação expressa do autor da herança, e os testamentos não são instrumentos comuns no direito sucessório brasileiro.

Verificou-se que o caminho para afastar o cônjuge sobrevivente da herança seria a decretação de sua indignidade, diante da constatação de alguma das condutas previstas na lei. Contudo, tal circunstância, se analisada exclusivamente à luz da norma positivada, não se propõe a atender o propósito de afastamento do cônjuge indigno da meação.

Por certo, o posicionamento dos juristas, em sua maioria, é de obediência cega à lei, afastando da herança o cônjuge indigno, mas não da meação. Todavia, não se podem negar as possíveis injustiças advindas desse entendimento, podendo, até mesmo, motivar a prática de atos atentatórios contra o cônjuge autor da herança. Defende-se que a lei não pode ser analisada e aplicada na sua frieza, sobretudo, porque ninguém pode se beneficiar do sofrimento alheio. 
Analisou-se a decisão proferida pelo Tribunal de Justiça do Estado do Rio Grande do Sul, pela qual se aplicou, analogicamente, as consequências da indignidade, como forma de afastamento do direito à meação, como forma de evitar o enriquecimento sem causa daquele que se beneficiou da própria torpeza.

Ante aos fundamentos analisados, conclui-se que o cônjuge que atenta contra a vida do autor da herança, além de não ter direito ao quinhão hereditário, por decretação de sua indignidade, não pode ter acesso à meação, sobretudo, como forma de não beneficiar aquele que cometeu ato ilícito como forma de adquirir patrimônio.

O estudo realizado mostrou-se interessante, uma vez que a descoberta de uma possibilidade de efetivação da justiça, contrariando a aplicação fria da lei, que pode, às vezes, ser tirana e injusta, é um fator que faz valer a pena a escolha da profissão do advogado, no cumprimento do propósito de construir um mundo melhor para todos. 


\section{REFERÊNCIAS}

ACQUAVIVA, Marcus Cláudio. Teoria Geral do Estado. 2.ed. São Paulo: Saraiva, 2000.

ACQUAVIVA, Marcus Cláudio. Dicionário Jurídico Brasileiro Acquaviva. São Paulo: Jurídica Brasileira, 2008.

BOBBIO, Norberto. Teoria Geral do Direito. Tradução Denise Agostinetti. São Paulo: Martins Fontes, 2007.

BRASIL. Constituição (1988). Constituição da República Federativa do Brasil. Brasília: Senado, 1988. Disponível em:

< http://www.planalto.gov.br/ccivil_03/Constituicao/Constituicao.htm<. Acesso em: 15 de Set. 2015.

BRASIL. Lei no 10. 406, de 10 de janeiro de 2002. Institui o Código Civil. Diário Oficial da União, Brasília, 11 de Jan. 2002. Disponível em:

<http://www.planalto.gov.br/ccivil_03/leis/2002/L10406.htm>. Acesso em: 15 de Set. 2015.

BRASIL. Lei nº 5.869, de 11 de janeiro de 1973. Código de Processo Civil. Diário Oficial da União, Brasília, 12 de Jan.1973. Disponível

em:<http://www.planalto.gov.br/ccivil_03/leis/L5869.htm>. Acesso em: 15 out. 2015.

BRASIL. Superior Tribunal de Justiça. Recurso Especial: 802372/MG. Relator: Ministra NANCY ANDRIGHI - Terceira Turma. Diário de Justiça Eletrônico, Brasília, 16 set. 2008. Disponível em:

<http://stj.jusbrasil.com.br/jurisprudencia/2353460/recurso-especial-resp-802372-mg-20050201434-1>. Acesso em: 16 out. 2015.

BROCHADO, Ana Carolina Teixeira; RIBEIRO, Gustavo Pereira Leite. Manual de Direito das Famílias e das Sucessões. 2.ed. Belo Horizonte: Del Rey, 2010.

CATEB, Salomão de Araújo. Direito das Sucessões. São Paulo: Atlas, 2012. Disponível em: $<$ http://integrada.minhabiblioteca.com.br/\#/books/9788522475087/pages/58934454>. Acesso em: 01 out. 2015.

CASTRO, Sérgio. Justiça oficializa exclusão de Suzane von Richthofen da herança dos pais. Disponível em: <http://g1.globo.com/sao-paulo/noticia/2015/03/justica-oficializaexclusao-de-suzane-von-richthofen-da-heranca-dos-pais.html>. Acesso em 20 jun 2016.

DIAS, Maria Berenice. Jurisprudências. Disponível em:

$<$ http://www.mariaberenice.com.br/jurisprudencia.php?subcat=1144>. Acesso em 17 out. 2015.

DINIZ, Maria Helena. Direito Civil: Direito das sucessões.16. ed. São Paulo: Saraiva, 2002. v. 6. 
FIUZA, Cézar. Direito Civil: curso completo. 17. ed. rev., atual. E ampl. São Paulo: Editora Revista dos Tribunais, 2014.

GOMES, Orlando. Sucessões. 12. ed. Atual. Rio de Janeiro: Forense, 2004.

GONÇALVES, Carlos Roberto. Direito das Sucessões. 15. ed. São Paulo: Saraiva, 2010. v. 4. (Coleção Sinopses Jurídicas).

HIRONAKA, Giselda Maria Fernandes Novaes; PEREIRA, Rodrigo da Cunha. Direito das Sucessões. 2. ed. Belo Horizonte: Del Rey, 2007.

MINAS GERAIS. Tribunal de Justiça. Processo: AC9572648-72.2008.8.13.0024 MG 1.0024.08.957264-8/001. Relator: Edgard Penna Amorim. $8^{a}$ Câmara Cível, Belo Horizonte, 22 jun. 2010. Disponível em:

<http://www.jusbrasil.com.br/diarios/86602155/djpe-26-02-2015-pg-806> Acesso em: 14 out. 2015.

MINAS GERAIS. Tribunal de Justiça. Processo: AC 10313100253225001 MG. Relator: Peixoto Henriques - $7^{\mathrm{a}}$ Câmara Cível, Ipatinga, 13 ago. 2015. Disponível em: < http://tj-mg.jusbrasil.com.br/jurisprudencia/116346799/apelacao-civel-ac$10313100253225001-\mathrm{mg}>$. Acesso em: 09 out. 2015.

MONTEIRO, Washington de Barros Monteiro. Curso de Direito Civil: Direito das sucessões. 35. ed. rev. e atual. São Paulo: Saraiva, 2003.

NADER, Paulo. Curso de Direito Civil: Direito das sucessões. Rio de Janeiro: Forense, 2010. v. 2.

NICOLAU, Gustavo Rene. Sucessão legítima no novo Código Civil. Revista IOB de Direito de Família, Porto Alegre. v. 9, n. 44, p. 48-58, out./nov. 2007.

PEREIRA, Caio Mário Pereira. Instituições de direito civil: Direito das sucessões. 22. ed. Atual. Rio de Janeiro: Forense, 2015.

RIO GRANDE DO SUL. Tribunal de Justiça. Processo: AC 70048120745 RS. Relator: Munira Hanna. Sétima Câmara Cível, Porto Alegre, 10 maio, 2013. Disponível em: < http://tj-rs.jusbrasil.com.br/jurisprudencia/112840263/apelacao-civel-ac-70048120745-rs>. Acesso em: 20 set. 2015.

RIO GRANDE DO SUL. Tribunal de Justiça. Processo: 1.10.0002677-2. Juiz Prolator: Paulo Meneghetti. Veranópolis, 30 nov, 2011. Disponível em:

<http://www1.tjrs.jus.br/site_php/consulta/consulta_sentenca.php?id_comarca=veranopolis\& num_processo $=11000026772 \&$ code $=6248 \&$ nomecomarca $=\&$ orgao $=$ Vara $\% 20 \mathrm{Judicial} \% 20: \%$ 201\%20/\%201>. Acesso em: 20 set. 2015. 
RIO GRANDE DO SUL. Tribunal de Justiça. Processo: AI 70052966645 RS. Relator: Alzir Felippe Schmitz. Oitava Câmara Cível, São Borja, 04 abril, 2013. Disponível em: $<$ http://tj-rs.jusbrasil.com.br/jurisprudencia/112800443/agravo-de-instrumento-ai70052966645-rs>. Acesso em: 05 out. 2015.

RIZZARDO, Arnaldo. Direito das Sucessões. Rio de Janeiro: AIDE Editora, 1996.

SÃO PAULO. Tribunal de Justiça. Processo: APL 788320058260627 SP 000007883.2005.8.26.0627. Relator: Claudio Godoy, $1^{\text {a }}$ Câmara de Direito Privado, Teodoro Sampaio, 25 out., 2011. Disponível em:

<http://tj-sp.jusbrasil.com.br/jurisprudencia/20672662/apelacao-apl-788320058260627-sp0000078-8320058260627-tjsp> Acesso em 06 out. 2015.

SÃO PAULO. Tribunal de Justiça. Processo: AI 20776974420158260000 SP 2077697. 44.2015.8.26.0000. Relator: Christine Santini. $1^{\text {a }}$ Câmara de Direito Privado, Mogi-Mirim, 19 maio, 2015. Disponível em:

< http://tj-sp.jusbrasil.com.br/jurisprudencia/190197315/agravo-de-instrumento-ai20776974420158260000-sp-2077697-4420158260000>. Acesso em: 22 set. 2015.

TARTUCE, Flávio. Manual de Direito Civil. 4. ed. São Paulo: Método, 2014.

VENOSA, Silvo de Salvo. Direito Civil: Direito das sucessões. 10. ed. São Paulo: Atlas, 2010. v.7. 